\title{
The therapeutic landscapes of two maternity hospitals in Ile-de-France
}

Clélia Gasquet-Blanchard, Alain Vaguet, Véronique Lucas-Gabrielli, Bruno Renevier and Elie Azria

\section{OpenEdition}

Journals

Electronic version

URL: https://journals.openedition.org/rfst/752

DOI: $10.4000 /$ rfst.752

ISSN: 2492-3672

This article is a translation of:

Les paysages thérapeutiques de deux maternités d'île-de-France - URL : https://

journals.openedition.org/rfst/522 [fr]

Publisher

Espaces et SOciétés (UMR 6590)

Electronic reference

Clélia Gasquet-Blanchard, Alain Vaguet, Véronique Lucas-Gabrielli, Bruno Renevier and Elie Azria, "The therapeutic landscapes of two maternity hospitals in Ile-de-France", Revue francophone sur la santé et les territoires [Online], Varia, Online since 13 November 2020, connection on 08 May 2021. URL: http:// journals.openedition.org/rfst/752 ; DOI: https://doi.org/10.4000/rfst.752

This text was automatically generated on 8 May 2021.

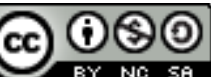

La Revue francophone sur la santé et les territoires est mise à disposition selon les termes de la Licence Creative Commons Attribution - Pas d'Utilisation Commerciale - Partage dans les Mêmes Conditions

4.0 International. 


\title{
The therapeutic landscapes of two maternity hospitals in Ile-de-France
}

\author{
Clélia Gasquet-Blanchard, Alain Vaguet, Véronique Lucas-Gabrielli, Bruno \\ Renevier and Elie Azria
}

1 Thanks to the "cultural turn", medical geography has produced a great deal of work on health, taking the health care places as an entry point (Gesler \& Kearns, 2002, Curtis, 2004). The purpose was to give them a broad scope that questioned the place of identity, human experience, body, environment and culture. Thus, places that had a reputation for caring, affecting health, and healing, have been documented by researchers and conceptualized under the term of therapeutic landscapes (Gesler, 2002). English-speaking researchers have thus published extensively in this direction. They ask how the design of a care space can interact with the relational dimension of the caregivers. But also how the use of places could claim to have a therapeutic dimension, or even improve the quality of care and the quality of life of the sick people living in these places (Gesler et al., 2004).

2 From this perspective, through the prism of the three sides of the therapeutic landscapes concept (physical, social and symbolic environment) (cf. figure), we have proposed to compare two French maternity hospitals of Paris metropolis. They were selected in respect of their different status, private and public.

1. the maternity hospital of the Groupe Hospitalier Saint-Joseph, a private health establishment of collective interest, located in the French capital.

2. the Centre hospitalier intercommunal public de Montreuil, located in a densely populated territory, located near the capital.

3 The main objective was to examine more specifically the layout of the care facilities and their appropriation by professionals in the specific context of maternity care, according to those two different socio-historical contexts.

In addition to the critical assessment of an extensive bibliography, the methodology of this research was based on two commented and collective visits, organised by a researcher at the request of the health commission of the French National Geography 
Committee (CNFG). It was set up for a small group of geographers dealing with health issues. The analysis focuses voluntarily and subjectively on:

1. the researchers 's appreciation of the therapeutic landscapes, during the visits

2. the verbatim reports of the visits commented by the professionals and their analysis

3. and latter in a second meeting, the discussions between researchers and professionals that took place during restitution seminars with the two hospital teams.

This methodology has many limitations: the scope of the research was on the interaction between two professions: geographers and medical doctors; no interviews of patients were undertaken.

6 The main result of this research shows that the theoretical entry by the three sides of the therapeutic landscapes is relevant to documenting hospitals as a wellness space. In addition, the doctors appreciated the concepts we introduced, saying that it opened them up to new ideas on the several dimensions of their work premises.

7 Basically, our objective was not to make a comparison of the two sites, but most of the discussions with professionals lead to this topic. As a matter of fact, few doctors switch from private to public, or from public to private. So they were interested to understand what was the "other side of the mirror", in the other maternity. It seemed that our presence acted as a mediation for an attempt at better mutual understanding.

While the health care practice and the commitment that accompanies it were found on both sites, the population base, as well as the management and the mission of these establishments, deeply differ. Care cannot be identical or even equitable, depending on its premises, its layout and the symbols it bears. The appropriation of places at SaintJoseph contrasts with the operational sites in Montreuil, much more intended to a collective medicine. The urgency or the strain of the public service, as well as the great commitment of caregivers to deal with the risk of unequal access to care, relegates to a background the necessary personalization for the most deprived. However, contrary to several clinics, Saint-Joseph is a hospital without exceeding fees, in a territory where the liberal sector 2 (GPs who charge much more than the Sécurité sociale reimburse) is dominant. Nevertheless, this ultimately leads to the selection of patients who remain more favoured than the Montreuil maternity hospital ones.

The latter is more focused on a modest population, that of its catchment area. Its operating objectives are guided by a strong desire to integrate associations and to meet specific demand (vulvar and clitoral reconstruction, diabetes). This looks like a pure symbolic approach of the "public service " type. It also illustrates in depth the representations of differentiated stakes and possibilities between Montreuil (a public service) and Saint-Joseph (a private foundation). But also a feeling of differentiated sorting and control methods - flagrantly operational for admissions to the public sector- or, on the contrary, self-regulated by the more "well-off " populations, highlighting places and providing information on more global territorial functioning.

Questioning places on their possibility of appearing as a soothing space or, conversely, their difficulty in being symbolically and socially appropriated by patients or professionals, brings us back to places in all their geographical and social dimensions: they are built at the crossroads between identity and health and participate more or less in the well-being of those who practise them and make them evolve. 
The hospital therapeutic environment

\section{Inpatient therapeutic environment}

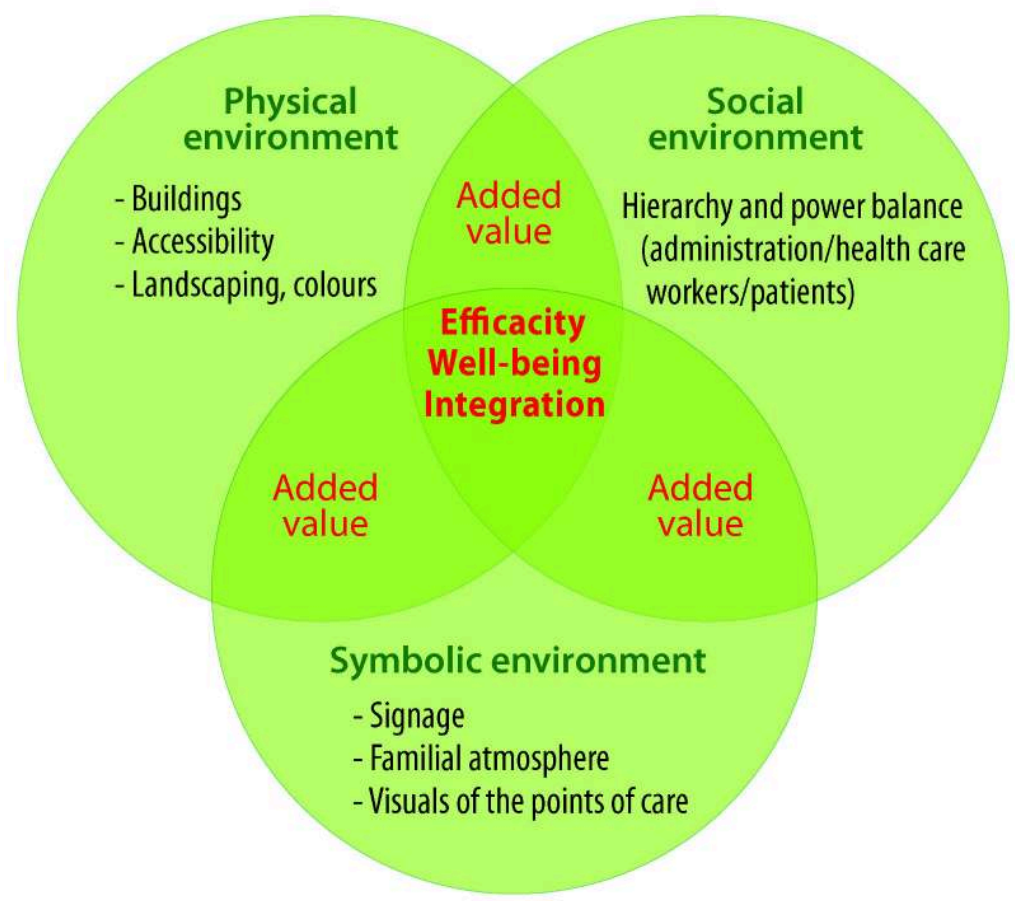

Source: Gesler (2002), Vaguet, Petit, Lefebvre (2012)

INDEX

Geographical index: île-de-France

Mots-clés: therapeutic landscape, maternity, care, well-being

\section{AUTHORS}

\section{CLÉLIA GASQUET-BLANCHARD}

Département des Sciences humaines, sociales et du comportement de l'EHESP ; UMR CNRS 6590, Espaces et Sociétés, Laboratoire Rennes 2

\section{ALAIN VAGUET}

Université de Rouen, Laboratoire IDEES, CNRS. Respectivement Président et secrétaire de la commission Géographie de la santé du Comité National Français de Géographie 


\section{VÉRONIQUE LUCAS-GABRIELLI}

Respectivement Président et secrétaire de la commission Géographie de la santé du Comité National Français de Géographie, Institut de Recherche et de Documentation en Economie de la santé (IRDES)

\section{BRUNO RENEVIER}

Service de gynécologie obstétrique, CHI André Grégoire, Montreuil, France

\section{ELIE AZRIA}

Maternité, Groupe Hospitalier Paris Saint-Joseph, Paris, France. Université de Paris, CRESS (Obstetrical, Perinatal and Pediatric Epidemiology Research Team, EPOPé), INSERM, INRA, F-75004 Paris, France 